\title{
ACTIVE STRUCTURES IN CENTRAL UPPER RHINE GRABEN, SW GERMANY: NEW DATA FROM LANDAU AREA USING ELECTROMAGNETIC RADIATION (EMR) TECHNIQUE
}

\author{
Wael Hagag \\ Department of Geology, Faculty of Science, Benha University, Benha, Egypt wael.hagag@fsc.bu.edu.eg
}

\begin{abstract}
Two conjugate sets of active faults oriented NNE-SSW and NNW-SSE have been detected at Landau area in SW Germany. These faults follow the old trends of the rift-related structures predominating in the Upper Rhine Graben, which originated during Late Eocene-Miocene time. Linear and horizontal measurements were performed by using the Cerescope device and interpreted, applying the Electromagnetic Radiation (EMR) Technique. Linear EMR-profiles were helpful for mapping active faults, while the main horizontal stress $\left(\sigma_{\mathrm{H}}, \mathrm{N}\right.$ to $\left.\mathrm{NNE}\right)$ was easily identified with EMR-horizontal measurements. Reactivation of rift-related structures of the Upper Rhine Graben at Landau area produces a new system of active shallow fractures following old trends, and has been detected through the present study by Cerescope applying the EMR-Technique. The present results imply that the Enhanced Geothermal System to the south of Landau has a great impact on reactivation of the pre-existing riftrelated faults by mechanical hydro-fracturing occurring within the reservoir rocks underneath the area.
\end{abstract}

Keywords: EMR-Technique, Active Faults, Upper Rhine Graben, Landau area.

\section{INTRODUCTION}

Application of geogenic electromagnetic radiation (EMR) in geosciences has been increased. The EMR technique facilitates the investigation of geological structures and related stress regimes. It is based on the natural electromagnetic waves emitting from brittle materials when exposed to mechanical stresses. That is an old phenomenon but in last few decades has been tested for applicability in the field of structural geology. Micro-fracturing related charge transfer is proposed to be the main source of the EMR among other possible processes. For basic facts on EMR and its application in structural geology and neotectonics, it is recommended to read the valuable works of Bahat et al. (2005) and Greiling and Obermeyer (2010).

The most promising theories to explain the generation of EMR induced by brittle fracturing are (1) charge separation processes between or along the crack walls associated with micro-cracking (O'Keefe and Thiel, 1995; Gershenzon et al., 1986), (2) crack-induced movement and reorientation of dislocations (Misra and Gosh, 1980; Slifkin, 1993), and (3) the surface vibrational-wave model (SVW) of Frid et al. (2003) and Rabinovitch et al. (2007). The model (3) is able to explain the generation of EMR independent of the material, as well as the directional properties of the emitted electromagnetic waves, which are the main requirements of a source mechanism. Furthermore, the SVW model is in accordance with further investigations of Frid et al. (1999), Rabinovitch et al. (2000, 2002) and Takeuchi and Nagahama (2006) who are able to explain the properties of the measured EMR waves with the crack dimensions and the material properties. Koktavy et al. (2004) propose a combination of the charge-separation models and the SVW model. It is therefore probable that more than one mechanism contributes to the generation of EMR associated with micro-cracking.

The previous publications based on the EMR-Technique and Cerescope are: Reuther et al. (2002), Lauterbach (2005), Lichtenberger (2005; 2006 a, b), Mallik et al. (2008), Reuther and Moser (2009).

The present study, in the same context, is the first attempt using the EMR-technique/method and Cerescope in surface detection, investigation and mapping of an active fracture system, beside the 
Hagag, W.

identification of the main horizontal stress direction $\sigma_{\mathrm{H}}$ at Landau area in the central Upper Rhine Graben, SW Germany (Fig. 1). To achieve the main objectives of the study, a grid of linear profiles was surveyed using Cerescope to define the locations of active faults, which deform the uppermost sedimentary cover. Horizontal measurements were also carried out to determine the direction of maximum EMR- intensities that is directly related to the orientation of the largest principal horizontal stress axis $\left(\sigma_{1}\right)$. The effect of the Upper Rhine Graben active tectonism and the Enhanced Geothermal System, south of Landau, on the seismicity and reactivation of an old rift-related fracture system will be discussed.

Fig. 1: Geographical map of the Upper Rhine Graben (URG), southwest Germany (left-side map) and a Google Earth satellite image (right-side image) of the study area at Landau. EBF, WBF, OGP and HTBF are boundary faults.

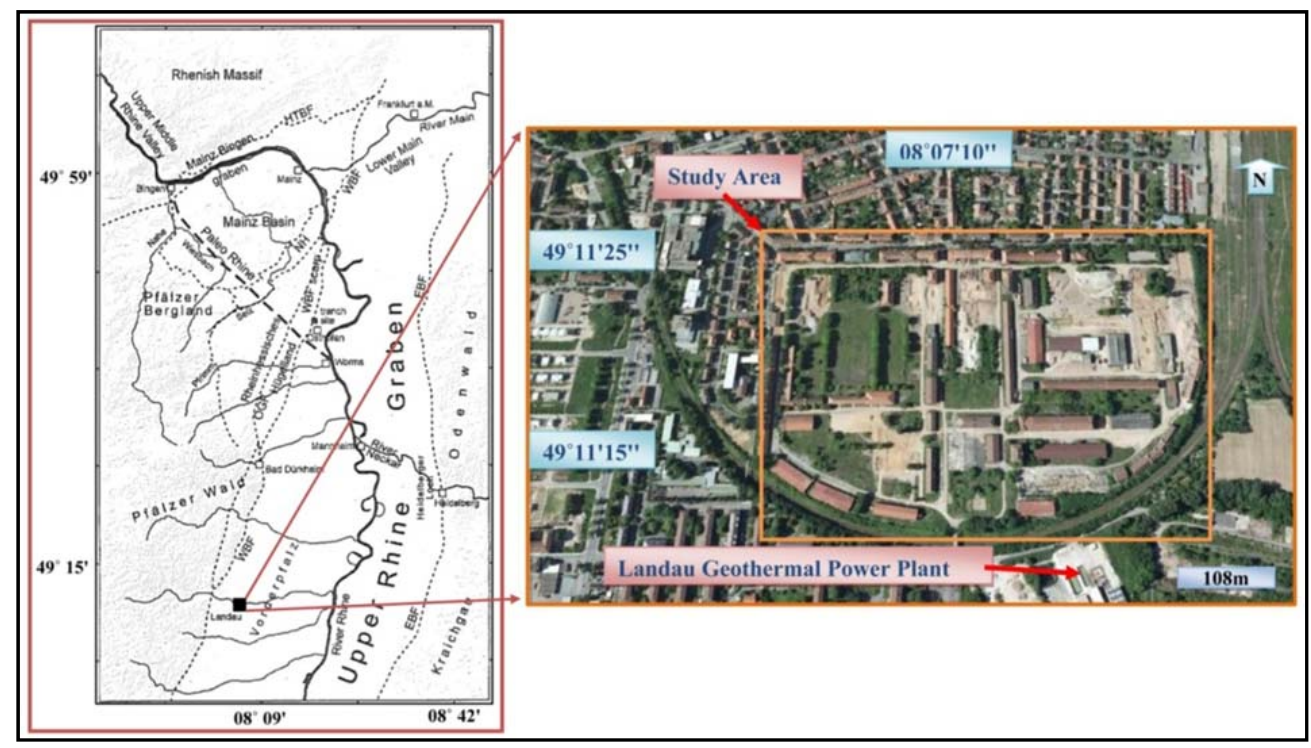

\section{METHODOLOGY}

\section{The Cerescope}

All EMR-measurements are performed with the Cerescope (Fig. 2). The hardware, adjustment steps and functionality of the Cerescope was described with details in Obermeyer $(2001,2005)$. The values measured by the Cerescope store as Parameters A to E. Parameter A is the number of peaks cross the assigned discrimination level, whereas the Parameter B defines the number of counted bursts. The Parameter $\mathrm{C}$ defines the average amplitude of the bursts, while the energy of bursts measured as Parameter D. Finally, the mean frequency of bursts is measured as Parameter E. Table 1 shows a typical data sheet. Parameters A and D are the most useful for meaningful interpretation.

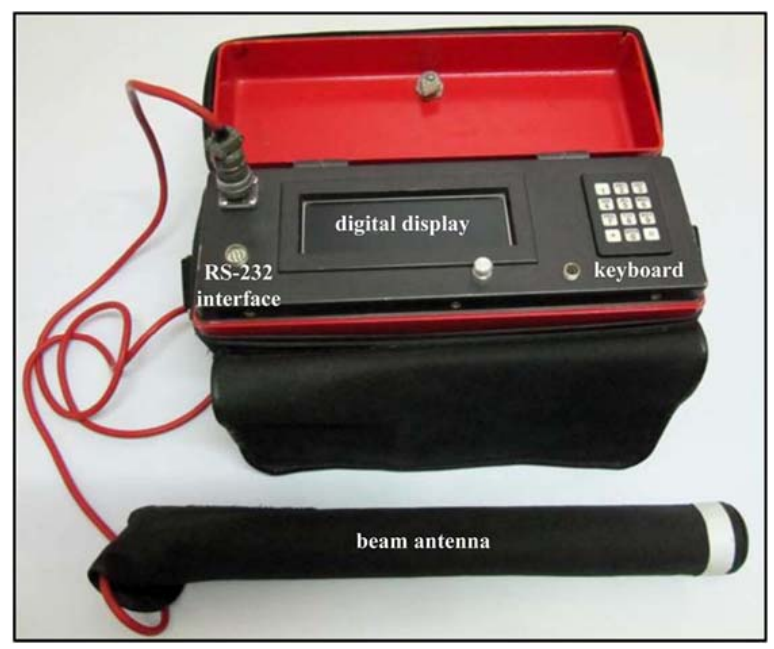

Fig. 2: The Cerescope device used in the present study 


\section{Active structures in central Upper Rhine Graben, SW Germany}

Table 1: A data file in Microsoft Excel recorded with Cerescope demonstrating the different EMR measured parameters.

\begin{tabular}{|c|c|c|c|c|c|c|c|}
\hline \multicolumn{2}{|l|}{ Object-Landau_ } & Profile $-\mathbf{1 8}$ \\
\hline Picket & Parameter A & Parameter B & Parameter C & Parameter D & Parameter E & Azimuth & Time \\
\hline 1 & 6 & 0 & 0 & 0 & 0 & 0 & $5 / 26 / 201412: 14$ \\
2 & 10 & 0 & 0 & 0 & 0 & 0 & $5 / 26 / 201412: 14$ \\
3 & 21 & 1 & 79 & 125 & 22 & 0 & $5 / 26 / 201412: 14$ \\
4 & 12 & 0 & 0 & 0 & 0 & 0 & $5 / 26 / 201412: 14$ \\
\hline
\end{tabular}

\section{Measurement procedures}

\section{Linear measurements}

Linear Cerescope measurements are recorded along linear profiles as described in Obermeyer et al. (2001). They carried out to detect the site of active faults and stress focuses. The linear measurements are usually carried out in the time-triggered mode and hence it needs a regular speed along the measured profile to produce a uniform distribution for the measuring points. So, in mountainous areas and long profiles of kilometers length the linear measurements can be taken with the car of regular speed to ensure a regular spacing between individual measurements.

\section{Horizontal measurements}

With horizontal measurements it is possible to determine the main horizontal direction of EMR. Assuming tensional micro- and nano-cracks as the source of EMR, the main radiation direction coincides with the preferred orientation of the cracks and therefore allows the determination of the direction of the main horizontal normal stress direction $\left(\sigma_{\mathrm{H}}\right)$.

During horizontal measurements the beam antenna is moved in a circle in the horizontal. Two procedures can be used. First, using a template with a $360^{\circ}$ azimuth, one person rotates the antenna stepwise in $5^{\circ}$ intervals, while a second person operates the Cerescope, resulting in 72 single measurements at each measuring location. This assures correct and highly reproducible results. An alternative method used is to mount the antenna onto an automatic turning device.

\section{EMR measurements at Landau area}

\section{Linear measurements}

A grid of linear EMR-profiles (12 profiles oriented N-S and 6 profiles oriented E-W) was designed and surveyed by the Cerescope (Fig. 3). The shortest and longest measured EMR-profiles were 126m (profile 10 due $\mathrm{N}$ ) and $661 \mathrm{~m}$ (profile 1 due E), respectively. The study area is a new urban area under construction, to the south of Landau city, subdivided by several routes (future streets), gardens and a few narrow corridors. We did not use a car but measuring while marching, in constant and regular steps, was carried out.

The Cerescope device was adjusted on a suitable discrimination or gain level (mainly the highest level of gain 3) during all measurements, with the Cerescope antenna oriented vertically, perpendicular to the ground surface. The measurements were operated during several days in May 2014, with optimum time and weather conditions suitable for EMR working. The time from 10:00 am until 03:00 pm was chosen to avoid the effect of the artificial signals from very low frequency transmitters (VLF), the daily fluctuation of the earth tides and irradiation from the sun (Lichtenberger, 2005). Although measuring EMR-profiles through urban areas, especially along streets, may subject the measuring process to disturbance by artificial sources of radiation like power lines, communication lines and television cables, water and gas pipelines, for linear measurements the effect of artificial sources is in most cases easy to detect. The pattern of the EMR-profile is characterized by a dramatically increase or decrease in EMR intensity towards these artificial sources.

The measured linear EMR-profiles are interpreted in the light of the data available from the previous publications and studies as we have not yet any standard profiles, curves or guided EMR-catalogs. On each profile the high intensities (summits) on the EMR intensity-curves are marked and numbered as 
Hagag, W.

peaks (Fig. 3a, b). Each peak can be separately interpreted to detect the nature of a fault or fracture emitting the signal. After projecting the different EMR-peaks of the intersected linear EMR-profiles, on a map with a suitable scale, the strike of the proposed faults could be traced (Fig. 4), whereas the dip (amount and direction) of these faults is easily identified from analyzing the asymmetric shape of the intensity-curves themselves. The intensity-curves of the northerly and easterly EMR linear-profiles of the study area were mutually interrelated to get a realistic view for the dimension and orientation of the detected faults.

a
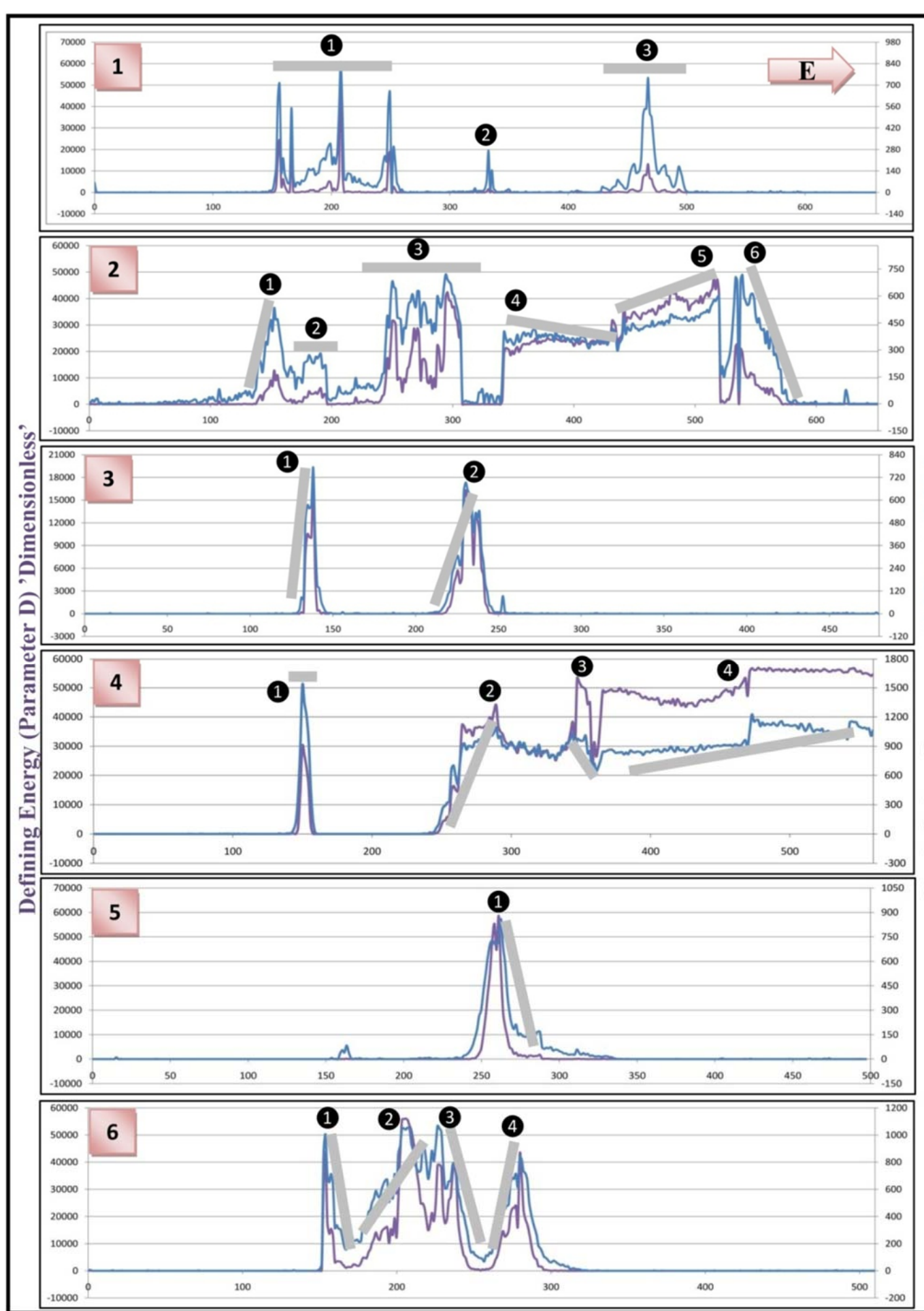
Active structures in central Upper Rhine Graben, SW Germany

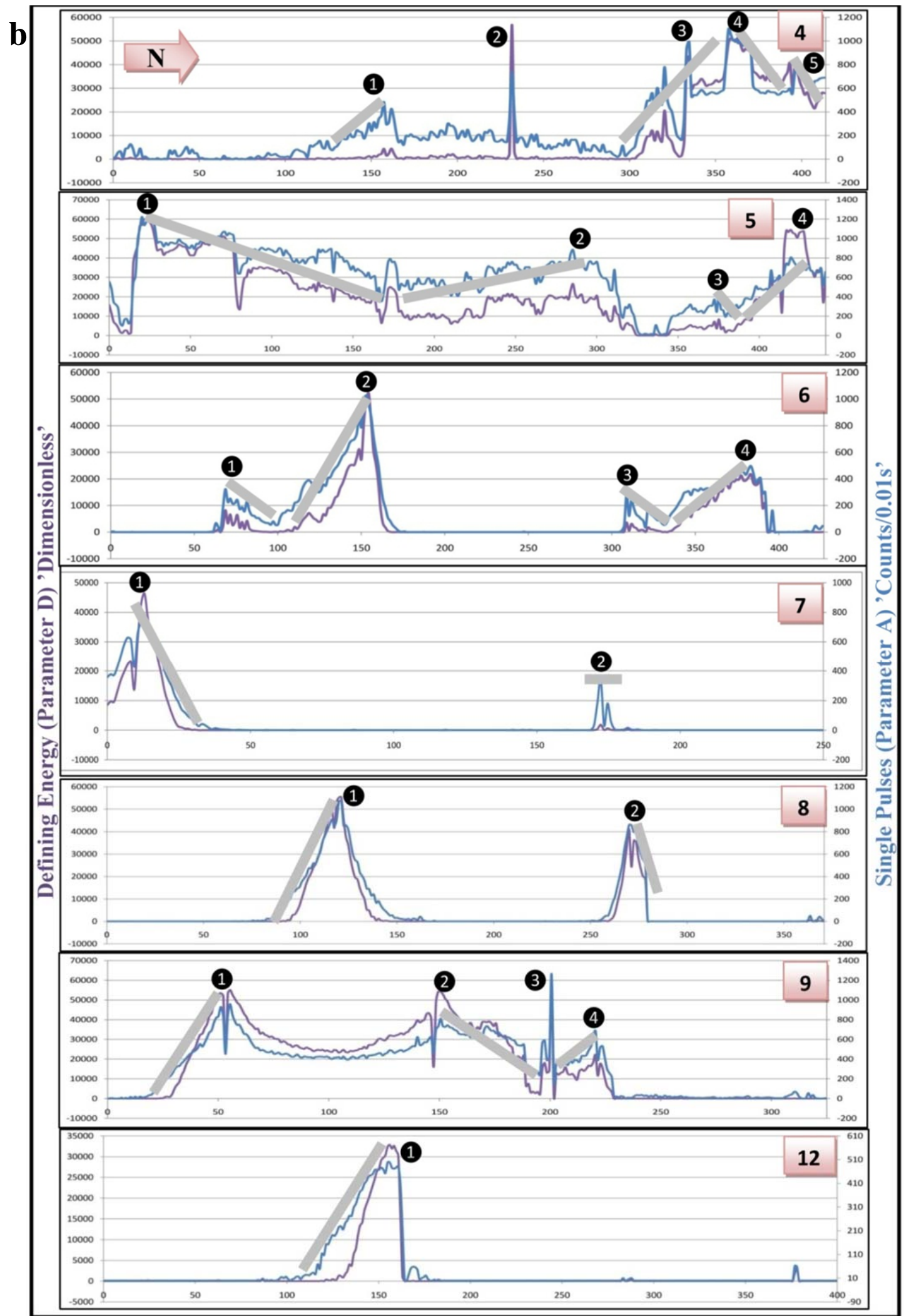


Hagag, W.

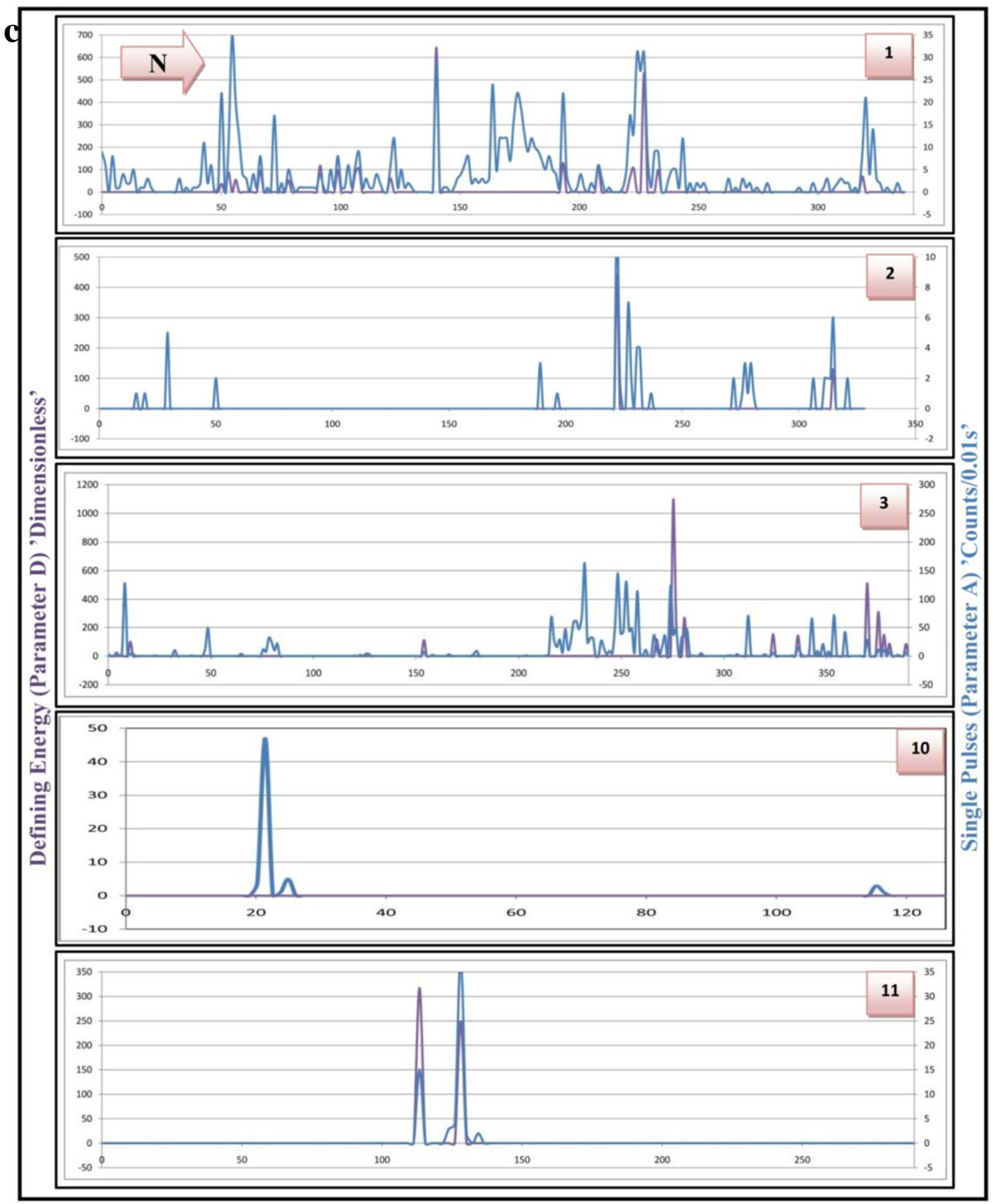

Fig. 3: Electromagnetic spectrum, intensity curves, of linear EMR-profiles measured due east (a) and north (b) directions; and the EMR-profiles which are highly disturbed by artificial signals (c).

Figure 3 demonstrates a possible interpretation for the different EMR-peaks identified from the different measured $\mathrm{E}$ and $\mathrm{N}$-oriented EMR-profiles. The horizontal grey lines define a very steep to subvertical fault represented by one distinct peak of a single fault or a fracture zone including several subpeaks of successive faults, while the inclined grey lines propose a shallow or steeply-dipping fault depending on the degree of inclination of the line. Based on the spatial distribution of the different EMRpeaks recorded along the intersecting eastern and northern profiles (plotted on the map in Fig. 4) and on the method of peak-interpretation discussed above, a system of NNE-SSW (in the southern part of the area) and NNW-SSE (in the northern part of the area) oriented fractures are postulated. These fractures are 


\section{Active structures in central Upper Rhine Graben, SW Germany}

arranged in two domains separated by a belt of ESE-WNW to E-W oriented left-stepping en echelon fractures (Fig. 5). The nature of this fracture system and the causal stress will be discussed in the next sections.

Fig. 4: Tracing map of the detected faults depending on the anomaly peaks of high EMRintensity. Red and blue peaks are arranged along the east- and northoriented EMRprofiles, respectively.
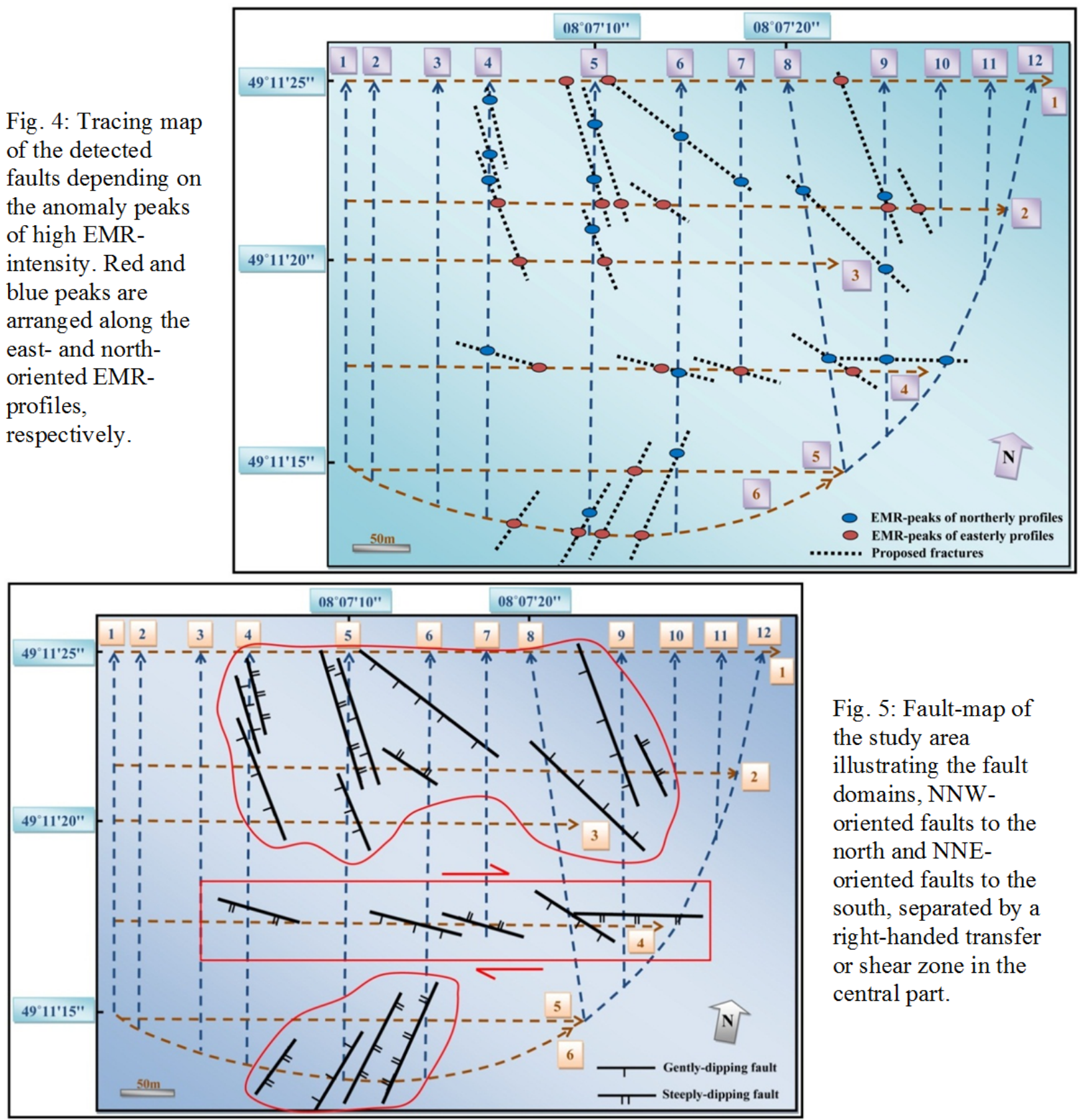

Fig. 5: Fault-map of the study area illustrating the fault domains, NNWoriented faults to the north and NNEoriented faults to the south, separated by a right-handed transfer or shear zone in the central part.

\section{Horizontal measurements}

Several horizontal EMR-measurements were taken along the study area at different locations, which are shown on the fracture map in Fig. 6. The purpose of performing such horizontal measurements by using the Cerescope is the identification of direction of the main horizontal stress $\left(\sigma_{H}\right)$. The horizontal measurements were plotted on polar diagrams in Fig. 7. 
Hagag, W.

Fig. 6: Horizontal measurements recorded by the Cerescope and projected on the fracture map of the study area.

Negative measurements mean that no EMR-signals were recorded.
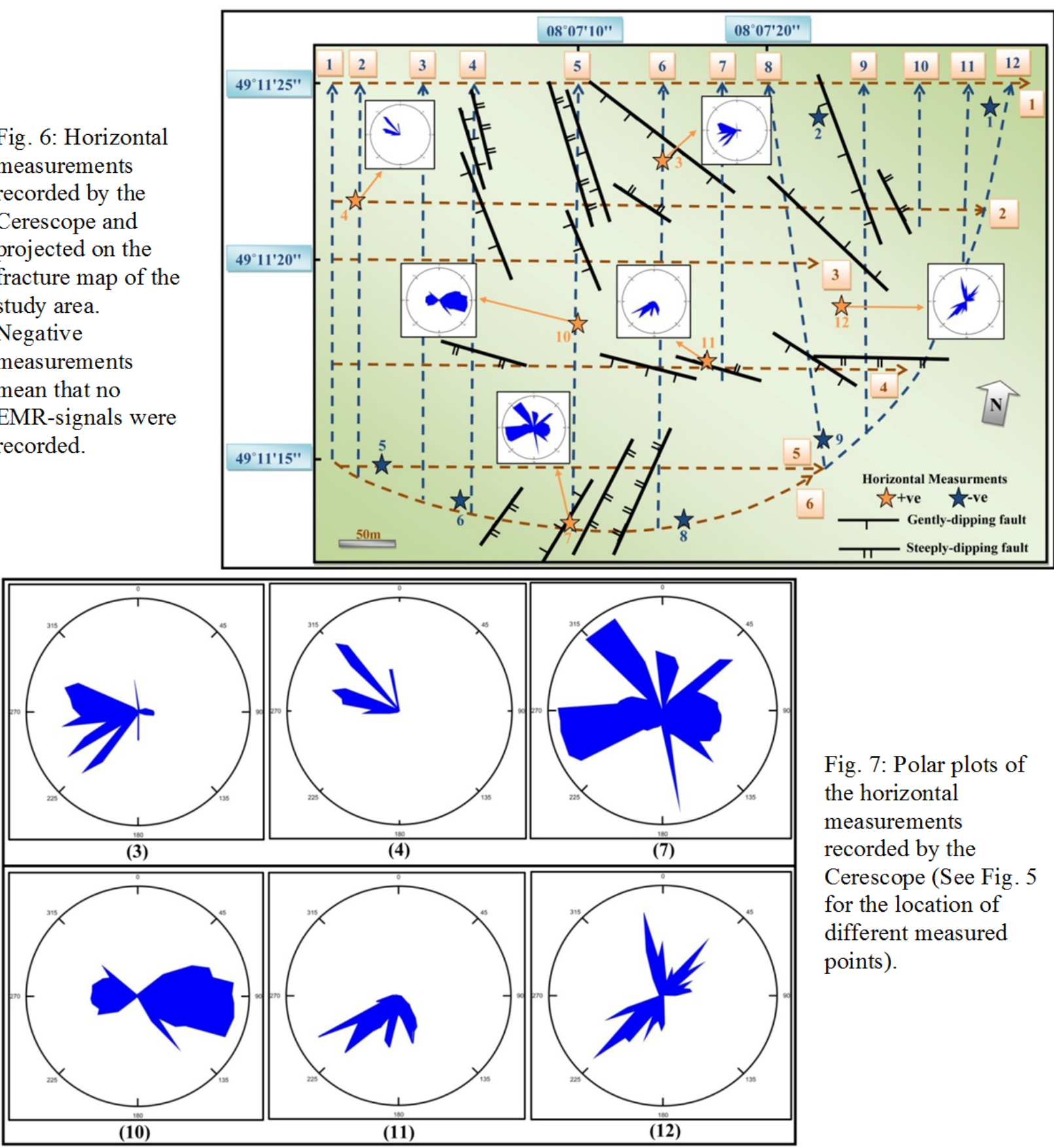

Fig. 7: Polar plots of the horizontal measurements recorded by the Cerescope (See Fig. 5 for the location of different measured points).

\section{DISCUSSION}

\section{Discussion of EMR measurements}

In the study area 18 linear EMR-profiles were measured and repeated horizontal EMR-measurements at 12 locations were performed, applying the EMR-technique using Cerescope. The results of the linear profiles are displayed as intensity-curves using parameter $\mathrm{A}$ and parameter $\mathrm{D}$ plotted on the same histogram (Fig. 3) to discriminate the natural geogenic-pulses of defined energy from the artificial ones of low energy but high pulsed peaks (see Fig.3c and peak 2 on profile 4 in Fig. 3b). EMR intensity-peaks are a main clue for interpretation of these profiles. A distinct single peak with simple intensity curve characteristics could represents a single fault (profiles 3, 5 in Fig. 3a and profiles 6, 7, 8, 12 in Fig. 3b), whereas another peak may define a fracture zone of closely-spaced steeply-dipping to sub-vertical fault 


\section{Active structures in central Upper Rhine Graben, SW Germany}

planes (peak 1 on profile 1 and peak 3 on profile 2 in Fig. 3a). However, several peaks represent a belt consisting of faults or fault segments forming en echelon arrangement (peaks 2, 3, 4 on profile 4 in Fig. 3 a; peaks $3,4,5$ on profile 4 in Fig. 3b). For a full map-view of these peaks and their related faults see the map in Fig. 4.

Interpretation of the linear EMR-profiles including analysis of the associated EMR intensity-curves resulted in, as shown on the fracture map of the study area in Fig. 4, a fracture system of normal dip-slip faults oriented NNE-SSW and NNW-SSE. The important characteristics of these faults are the en echelon arrangement and the graben and horst structural style, along their trend, i.e. they have oppositely dipping surfaces along the same profile. As EMR-measurements make it possible to detect faults and make predictions about the dip direction and the strike by combining different linear measurements, the normal sense of displacement along the detected faults could be estimated from the shape of their different EMR intensity-curves, especially when the structural and tectonic regime of the area is well known. However, the strike-slip component is difficult to be estimated depending on the linear EMR-measurements alone. Greiling and Obermeyer (2010) gave much attention to the tectonic setting of the investigated areas, while discussing the application of the EMR-study results in different tectonic environments. The distribution of these faults is also of great significance, where the NNE-SSW oriented faults are situated to the southwest while the NNW-SSE oriented faults are located to the north. Furthermore, the central area in between the two fault-trends is deformed by a differently oriented set of faults, oriented ESE-WSW to E-W with a lefthanded en echelon arrangement. The en echelon arrangement postulates shorter lengths for these faults than the NNE and NNW oriented faults. Fault propagation and growth models (e.g. Childs et al., 2003; Schlagenhauf et al., 2008) propose that faults which tend to arrange en echelon, within transfer or wrench zones, are forming with shorter fault-segments than one long major fault.

As outlined in detail by Lichtenberger (2006a) and Reuther and Moser (2007), a single peak of EMR is interpreted as due to an extensional fracture, where the direction of the fractures is parallel with that of the maximum horizontal stress. Accordingly, two or four peaks can generally be related to shear fractures and the maximum horizontal stress direction, in that case, is in the direction of the bisector of two conjugate peaks. The results of horizontal EMR-measurements of the study area (Fig. 6,7) point to two main radiation directions, NNE and NNW, although demonstrating a complex pattern. These trends can be interpreted as to define two conjugated sets of fractures, where the acute bisectrix of both sets is consistent with the maximum horizontal stress direction and suggesting $\mathrm{N}$ to NNE direction of $\sigma_{1}$.

To sum up, the linear EMR-measurements led to two fault-domains separated by an accommodation or shear zone (Fig. 5). The northern fault-domain comprising the NNW oriented faults, while the southern fault-domain consists of the NNE oriented faults. Geometrically, the two fault-trends would be interpreted as a set of conjugate fractures. The bisectrix between the conjugated NNE (N025 $\left.-030^{\circ}\right)$ and NNW $\left(\mathrm{N} 160^{\circ}-170^{\circ}\right)$ oriented faults proposed an applied regional stress $\sigma_{1}$ (shortening) directed $\mathrm{N}$ to $\mathrm{NNE}$ $\left(\mathrm{N} 005^{\circ}-007^{\circ}\right.$ ) with a maximum extension (lengthening) in E to ESE direction (N095 $\left.-097^{\circ}\right)$. The acute angle between these faults is on average $35^{\circ}-50^{\circ}$. Left-stepping faults forming the central shear zone suggest a right-lateral wrenching deforming the central part of the study area. Wrenching zones are characteristic for recent tectonics not only at Landau area but along the entire Upper Rhine Graben, as well. The direction of the main horizontal stress interpreted from the horizontal EMR-measurements (the main radiation directions) is, however, consistent with the direction estimated from the fracture analysis of the linear EMR-profiles.

\section{Landau area and the Upper Rhine Graben}

The Upper Rhine Graben (URG) is located at the center of the European rift system of Cenozoic age, which comprises several rift-formed basins covering the area from the North Sea in the north to the Gulf of Lyon in the south (Schumacher, 2002; Berger et al., 2005; Ustaszewski and Schmid, 2007; McCann, 2008; Rotstein and Schaming, 2011; Fuhrmann et al., 2012). The dimension of the URG is about $300 \mathrm{~km}$ long by $40 \mathrm{~km}$ wide, and is delineated from the north by the Rhenish Massif and from the south by foreland thrusts of the Jura Mountains. 


\section{Hagag, W.}

The structural orientations of the Upper Rhine Graben have been developed during the Paleozoic in relation to the Variscan Orogeny, and during the subsequent Permo-Carboniferous wrench related tectonics (Ziegler, 1990). The Variscan trend is dominant and characterized by NNE oriented left-lateral faults which are synchronously formed with the Lower Carboniferous-Permian intrusives outcropping in the basement of the Vosges Mountains in France,the Black Forest in Germany, and the Odenwald Mountains in Germany. This led Cloos (1922) and Illies (1962) to assume that the Late Variscan Shear Zone area is a precursor of the later on formed URG in Cenozoic time. Furthermore, the geophysical and tectonostratigraphic data in Edel and Weber (1995) and also in Schumacher (2002) proposed additional evidence on a major NNE trending Late Variscan shear system dissecting the area of the Upper Rhine Graben. However, the NE-ENE and NW Variscan trends are also encountered in the URG. High rates of Quaternary surface processes, intensive human modification, relatively slow tectonic deformation and presently low intra-plate seismic activity characterize the central and northern parts, including the study area, of the URG. Meanwhile, the southern URG is characterized by moderate to high level seismic activity as it abuts the northern margin of the Miocene to Pliocene fold and thrust belt of the Jura Mountains that experience ongoing tectonic activity (Ustaszewski and Schmid, 2007).

On a regional scale, the URG developed by passive rifting in the foreland of the Alps. The rifting was initiated by an E-W extension, occurring approximately contemporaneous with the collisional phases of the Alpine and Pyrenean orogenies (Villemin et al., 1986; Larroque and Laurent, 1988; Dezes et al., 2004). It was marked by Middle Eocene synrift sediments revealed from seismic and borehole data (Wittmann, 1955; Sittler and Sonne, 1971; Illies, 1977; Sissingh, 1998). The URG developed in two main phases. During the Oligocene crustal extension (first phase), preexisting weakness zones were reactivated in an overall extensional to transtensional stress field with E-W oriented extension. The individual basins coalesced, resulting in the development of the NNE-SSW striking Upper Rhine Graben. The graben structure opened and sedimentation occurred across the entire graben. The Early to Late Miocene time (second phase) was marked by a major reorientation of the regional stress field, which is responsible for the main subsidence phase of the northern parts of the URG and a reactivation of the URG system by leftlateral shearing, persisting until present (Illies, 1975; Schumacher, 2002; Michon et al., 2003; Dezes et al., 2004). A NW-SE oriented compression and a NE-SW oriented extension were prevailing during such phase.

The seismicity of the URG is characterized by low to moderate intra-plate earthquake activity (Ahorner, 1983; Bonjer, 1997; Leydecker, 2005). The URG is at present amongst the most seismically active areas in Western Europe north of the Alps. The historical seismic catalogue of the URG area is dated back to $800 \mathrm{AD}$ (Leydecker, 2005). The map of the instrumental and historical earthquakes in the URG shows a wide distribution of small earthquakes occurring over the entire graben (Fig. 8).

The tectonic regime in the central URG including the Landau area is extensional with a minor strikeslip component, where the maximum horizontal stress $\left(\mathrm{S}_{\mathrm{H}}\right)$ is oriented NW-SE (Bonjer et al., 1984; Delouis et al., 1993; Plenefisch and Bonjer, 1997; Hinzen, 2003). Recent modeling of strain rates across the URG based on the velocity measurements of continuously operating GPS stations, revealed a gradual change from transpression in the southern URG to transtension in the northern URG (Tesauro et al., 2005). This result confirms the decrease of compression from south to north, which has been suggested by the seismological studies (Ahorner et al., 1983; Delouis et al., 1993; Plenefisch and Bonjer, 1997). Based on GPS measurements and modeling studies on the GPS velocities, the crustal motions of the URG area are characterized by NW directed horizontal compressional rates between 0.1 and $2.9 \mathrm{~mm} /$ year with an EW extension of 0.5 to $1.5 \mathrm{~mm} /$ year (Vigny et al., 2002; Nocquet and Calais, 2004; Rozsa et al., 2005; Tesauro et al., 2005 and 2006).

The NNE-SSW trending URG, under the present day stress field, is subjected to sinistral transtension with NW directed horizontal stress $\left(\mathrm{S}_{\mathrm{H}}\right)$. The direction of $\mathrm{S}_{\mathrm{H}}$ in the URG area is on average NW-SE (N150) as demonstrated in the World Stress Map (Fig. 9) (WSM, Heidbach et al., 2008). However, for the Landau area, there is no published stress-depth distribution available. Rotation of the $\mathrm{S}_{\mathrm{H}}$ from NW-SE to NNW-SSE was observed with increasing depth (Cornet et al., 2007). 


\section{Active structures in central Upper Rhine Graben, SW Germany}

Fig. 8: Instrumental and historical earthquakes in the Upper Rhine Graben (URG) (source data: Fracassi et al., 2005 and Leydecker, 2005). The map shows a wide distribution of the small earthquakes occurring over the entire graben.

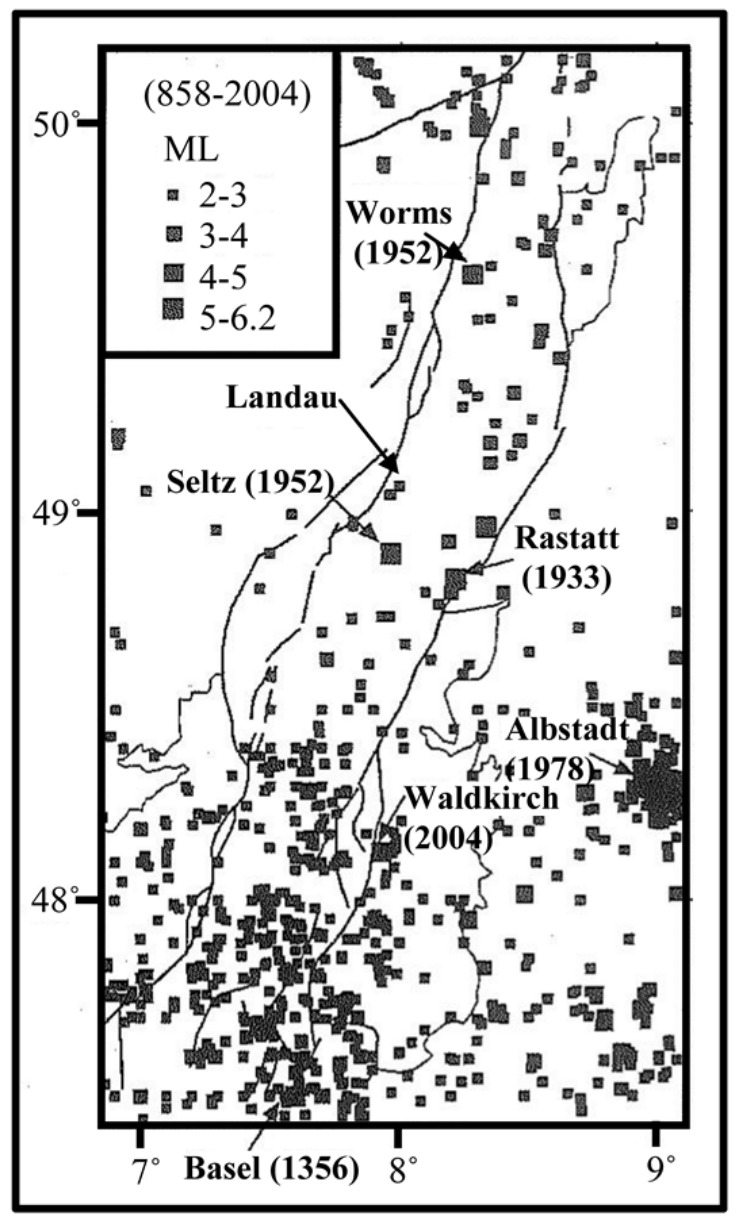

Based on 2D seismic profile interpretations, neotectonic fault activity is assigned mainly to $170^{\circ}-180^{\circ}$ striking faults, which are defined by Illies and Greiner (1978) as Riedel Shears with a left-lateral sense of movement. Recent seismological studies confirmed the seismic activity of $020^{\circ}$ striking faults located in the southern and central URG, which are associated with important historical earthquakes that could be well localized (Fracassi et al., 2005; Lopes Cardozo et al., 2005). The studies of Gaßner et al. (2014) and Frietsch et al. (2014) on Landau (study area) and Insheim areas that depend on the fault plane solutions of the micro-earthquakes together with the relative locations of the hypocenters proposed a prevailing NNWSSE striking normal faulting regime with a variable minor dextral strike-slip component. They suggested reactivation of pre-existing faults or opening of new fractures that follow the trend of the old ones. The maximum horizontal stress direction $\left(\mathrm{S}_{\mathrm{H}}\right)$ was postulated to be NNW-SSE.

The slip tendency (ST) model results (Peters, 2007) for the URG faults show that the magnitude of ST is strongly depending on the fault orientation. NE-SW trending faults show relatively low ST values, while N-S trending faults exhibit the highest ST values. Faults with largest ST values strike $160^{\circ}$ to $170^{\circ}$ (NNW-SSE), which is nearly parallel to the direction of $\mathrm{S}_{\mathrm{H}}$. Faults with intermediate ST values have main strike directions of $020^{\circ}$ (NNE-SSW) and $120^{\circ}$ (NW-SE), whereas the faults of low ST values are oriented nearly perpendicular to the maximum horizontal stress with a strike of about $065^{\circ}$ (ENE-WSW). Using finite-element modelling, Buchmann (2008) found that high values for dilatation-tendency and sliptendency prevail for faults which strike in NNW-SSE to NNE-SSW direction in the northern and central Upper Rhine Graben. Peters and Van Balen (2007) based on the tectonic geomorphology find also NNWSSE oriented fault trends inside the northern and central Upper Rhine Graben.

According to the previous discussion, the majority of faults, especially the fault sets striking $020^{\circ}$ and $170^{\circ}$, within the URG are optimally oriented for fault reactivation. The fault-trends detected during the present work, using the EMR-Technique and Cerescope, are very close to these trends. The effect of the 
Hagag, W.

complex tectonic setting and recent activity of the URG are obvious on the results of the present study. The direction of the maximum horizontal stress, which is assigned N-S to NNE-SSW during the horizontal EMR-measurements in the present work, is slightly deviating from that detected in NNW-SSE direction through the previous studies and tectonic models. This NE deviation may be interpreted as the main horizontal stress is rotated with depth, especially where these studies are mainly depending on the focal plane solution mechanisms (i.e. Gaßner et al., 2014; Frietsch et al., 2014), and on the subsurface bore-hole data and break-out measurements like Peters (2007) and Buchmann (2008). At greater depth, within the basement of both URG and Jura Mountains, the direction of present-day maximum horizontal stress is consistently oriented NW-SE (Plenefisch and Bonjer, 1997; Kastrup et al., 2004), while the recent stress field in the sedimentary cover (Mesozoic to Tertiary) as estimated from in-situ stress measurements, reveals NNW, N to NNE oriented maximum horizontal stresses (Becker 1999, 2000). Anticlockwise rotation of the maximum horizontal stress from the sedimentary cover to basement (Ustaszewski and Schmid 2007) indicates ongoing mechanical decoupling of the sedimentary cover from its basement along Early Mesozoic weak layers (Ustaszewski et al. 2005a, b).

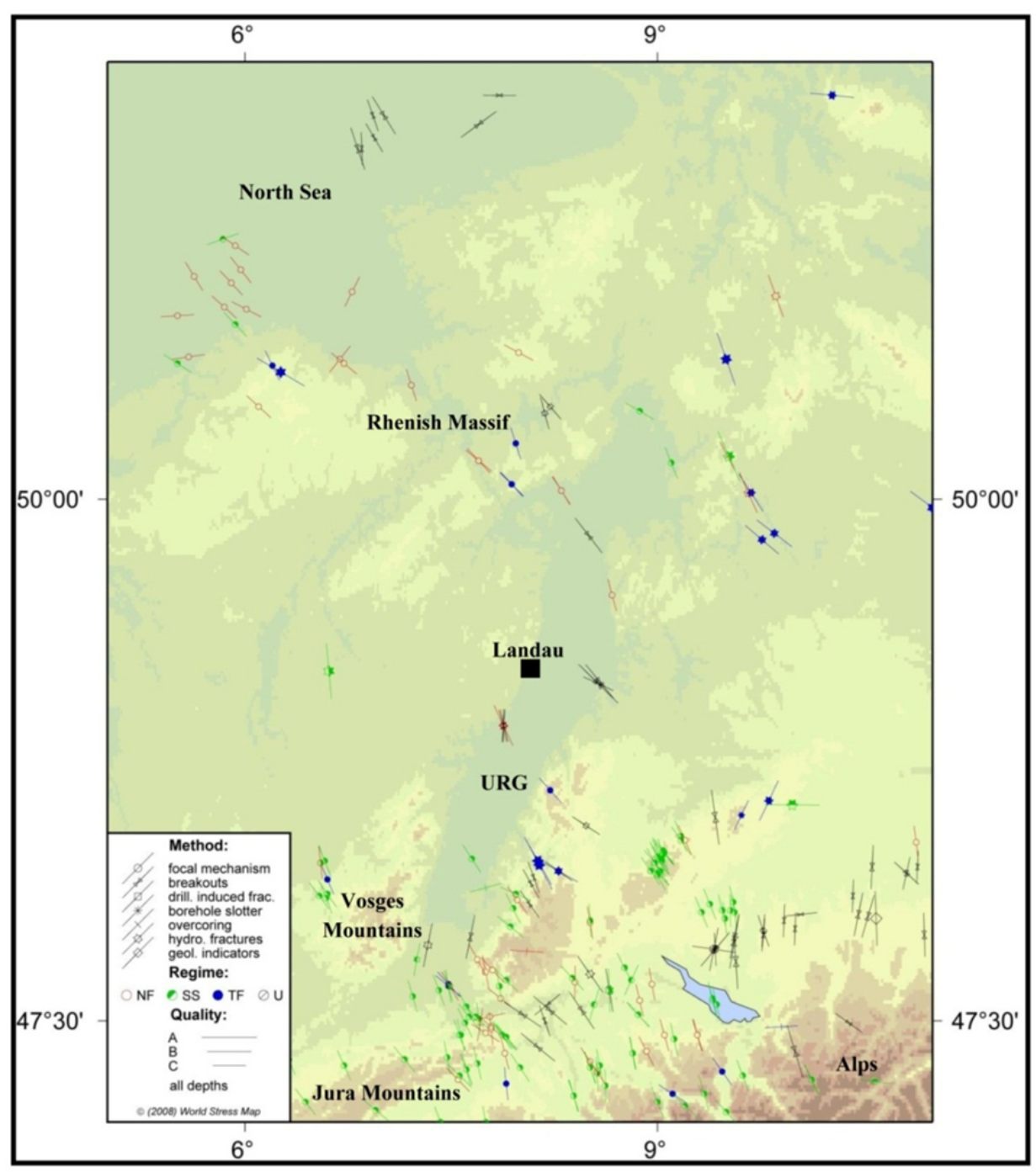

Fig. 9: The

maximum horizontal stress directions $\mathrm{S}_{\mathrm{H}}$ for the Upper Rhine Graben (URG) areas as demonstrated on the World Stress Map (WSM), Heidbach et al. (2008). Realize the recorded data at the northern and southern URG (the main direction is NW-SE), whereas no date recorded at Landau area.

\section{Effect of the Enhanced Geothermal System (EGS) to the south of Landau}

The Upper Rhine Graben (URG), in SW Germany, is the geothermal province with the highest geothermal gradients in Germany. Exploration wells show geothermal gradients up to $7.7^{\circ} \mathrm{C} / 100 \mathrm{~m}$. Prerift sedimentation is represented by Early to Middle Triassic deposits of the fluvial Buntsandstein and 


\section{Active structures in central Upper Rhine Graben, SW Germany}

marine Muschelkalk formations, which are overlying the crystalline basement. These formations, beside the basement, are actually the main geothermal reservoirs in this region.

One geothermal power plant is operating since 2007 in the city of Landau and a second power plant became operational in autumn 2012 near Insheim to the east of Landau. Furthermore, several geothermal power plants are currently projected in this region. In 2009 two earthquakes with magnitudes (ML) of 2.4 and 2.7 occurred directly underneath the city of Landau at $2.5-3 \mathrm{~km}$ depth in vicinity of the geothermal reservoir. These seismic events were felt inside a radius of several kilometers. Groos et al. (2012) found a mainly normal-faulting component for the two earthquakes which is in accordance to the extensional stress regime in this part of the Upper Rhine Graben.

The fluid injection in boreholes is usually carried out during industrial operations targeted to permeability enhancement of hydrocarbon reservoirs and geothermal heat exchangers. Pressures in the order of $10 \mathrm{MPa}$ are used in order to decrease the effective normal stress that results in shearing of preexisting fractures and/or creating new tensile fractures. A part of the deformation is brittle, which is expressed in the form of small seismic events. Accordingly, treatments of geothermal fields which are often associated with small-magnitude earthquakes $\left(\mathrm{M}_{\mathrm{L}}\right.$ from 2 to 4$)$ are representing a source for the seismic risk of these operations.

In hydrothermal and geothermal industries, active faults are the main target because of the mechanical fracturing is to some extent prevent deposition of minerals dissolved in geothermal fluids. Faults with large displacements are mostly developing cores that decrease the permeability of a fault due to clay and phyllosilicate mineral overgrowth (Yielding et al., 1997). As a consequence, fracture porosity could be reduced due to mineral precipitation (Knipe, 1997) and the ongoing deformation should dynamically counteract the fracture sealing through generating new fractures. Tensional to transtensional faults are the most important ones, where the formed fractures could stay open and accordingly increase the porosity and the permeability of the fault or damage zone. Several hydro-geothermal systems are associated with active faults and/or fault systems. Among them are the hydro-geothermal power plants near Landau and Bruchsal, the Great Basin in the western United States (Faulds et al., 2006 and 2010) as well as hydrogeothermal systems in the western Turkey. Such examples enhance the role of active fault systems (normal, dip-slip and wrench) in geothermal industry. In Enhanced Geothermal Systems (EGS), the permeability of the reservoir rocks has been increased by hydro-fracturing. High pressure, cold water is pumped down an injection well to increase fracture permeability and hydraulically stimulate geothermal resources. Hot water is extracted from the pumping well and is then ready for power generation in steam state or using a binary-cycle power plant. Enhanced Geothermal Systems are in the Upper Rhine Graben at Landau City in Germany (Bächler et al., 2003) and Soultz Sous Forets in France (Gerard et al., 2006). At Landau Pfaltz (Germany), the Enhanced Geothermal System (EGS) produces about 3 MW of electricity (2007), with a thermal capacity of about 3 MW (2010) for district heating, as a secondary operation. The Borehole depth is $3000-3340 \mathrm{~m}$ and the reservoir temperature is $160^{\circ} \mathrm{C}$. The horizontal distance at the surface between the injection and production wells is $5 \mathrm{~m}$, while at the subsurface this distance reaches $1.5 \mathrm{~km}$.

From the aforementioned discussion, the Landau area (including the area studied) has been affected by the processes of mechanical hydro-fracturing occurring in the reservoir rocks underlying the geothermal power plant. The stimulations of the reservoirs below Landau are accompanied by microseismicity (Plenkers et al., 2013; Groos et al., 2013). This seismicity indicates the generation of new cracks or the reactivation of existing faults. Under the stress conditions and fracture analysis described in the present study, it can be expected that these cracks and faults are aligned preferably in the NNW-SSE to NNESSW direction. Hot water $\left(165^{\circ} \mathrm{C}\right)$ with significant flow rates is extracted from faults at about $2-2.5 \mathrm{~km}$ depth at the geothermal power plant in Landau, Schindler et al. 2010. Therefore, it is obvious that the cracks are fluid-filled in the region of anisotropic wave propagation, Frietsch et al. (2014). The detected fracture system at Landau area, applying the EMR-Technique and Cerescope, is proposed to be newly formed. This argument is built on the following facts: (1) the processes of mechanical hydro-fracturing and reservoir stimulations occurring below Landau area have a tendency to generate new cracks in reservoir rocks, which suggested to propagate upward affecting the overlying sedimentary cover; (2) the 
Hagag, W.

accompanied microseismicity indicates reactivation of pre-existing faults, where repeated movements along such large active faults enhance fracturing processes (Knipe, 1997); (3) ongoing mechanical decoupling between the sedimentary cover and its basement (Ustaszewski and Schmid 2007) with rotation of a maximum horizontal stress from greater depths to shallow crustal levels, suppose a new system of fractures deforming the sedimentary cover and controlled by old trends. The detected fractures in Landau area trend NNE-SSW and NNW-SSE, estimating an N to NNE oriented maximum horizontal stress which rotated with depth to $\mathrm{NW}$ direction.

\section{CONCLUSIONS}

Applying the EMR-Technique using Cerescope at Landau area in the central Upper Rhine Graben (URG) resulted in detection of two conjugated sets of active faults following the same trends characterizing the rift-related tectonics predominating in the URG during the Late Eocene-Miocene time span. Linear and horizontal EMR-measurements were performed using a Cerescope device for mapping the active faults and determining the direction of maximum horizontal stress $\sigma_{1}$, respectively. The study demonstrates that the NNE-SSW and NNW-SSE fault trends are still active. The main direction of horizontal stress is represented by the acute bisectrix between the two preferred orientations. The maximum horizontal stress $\left(\sigma_{1}\right)$ is generally directed $\mathrm{N}$ to $\mathrm{NNE}\left(\mathrm{N} 5^{\circ}-7^{\circ} \mathrm{E}\right)$. Mechanical hydro-fracturing occurring in the reservoir rocks underlying the Enhanced Geothermal System at Landau area causes reactivation of the pre-existing deep-seated (basement) faults that are controlled by a complex structural and tectonic setting of the Upper Rhine Graben. Reactivation of the old fault-trends is deforming the uppermost sedimentary fill by creation of a newly active system of fractures, which follow the same orientations and induce active seismicity.

\section{ACKNOWLEDGMENTS}

The author would like to thank Prof. Dr. Reinhard Greiling (KIT, Karlsruhe) for a fruitful discussion about the EMR-results. Author thanks also Prof. Dr. Joachim Ritter for useful discussion about his recent seismological studies at Landau and Insheim. Thanks are extended to the GE\&O Karlsruhe (Company of exploration and radiolocation, Karlsruhe, Germany) and Dr. Hennes Obermeyer for providing the author with a Cerescope device to conduct this study.

\section{REFERENCES}

Ahorner, L. (1983): Historical seismicity and present-day microearthquake activity of the Rhenish Massif, Central Europe. In: J.H. Illies et al. (Editors), Plateau Uplift: The Rhenish Massif- A case History. Springer Verlage, Heidelberg, 198-221.

Ahorner, L.; Baier, B.; and Bonjer, K.P. (1983): General pattern of seismotectonic dislocation and the earthquake generating field in Central Europe between the Alps and the North Sea. In: J.H. Illies et al. (Editors), Plateau Uplift: The Rhenish Massif- A case History. Springer Verlage, Heidelberg, 187-197.

Bächler, D.; Kohl, T. and Rybach, L. (2003): Impact of graben-parallel faults on hydrothermal convection: Rhine Graben case study. Phys. Chem. Earth 28, 431-441.

Bahat, D.; Rabinovitch, A. and Frid, V. (2005): Tensile fracturing in rocks-tectonofractographic and electromagnetic radiation methods. Springer 16, $570 \mathrm{pp}$.

Becker, A. (1999): In Situ Stress data from the Jura Mountains-new results and interpretation. Terra Nova 11, 9-15.

Becker, A. (2000): The Jura Mountains-an active foreland fold-and-thrust belt. Tectonophysics, 321, 381406.

Berger, J. p.; Reichenbacher, B.; Becker, D.; Grimm, M.; Grimm, K.; Laurent, P.; Andrea, S. and Claudius, P. (2005) Eocene-Pliocene time scale and stratigraphy of the Upper Rhine Graben (URG) and the Swiss Molasse Basin (SMB). Intern. J. Earth Sci. 94, 711-731.

Bonjer, K. P. (1997): Seismicity pattern and style of seismic faulting at the eastern borderfault of the southern Rhine Graben. Tectonophysics 275, 41-69.

Bonjer, K.P.; Gelbke, C.; Gilg, B.; Rouland, D.; Mayer-Rosa, D. and Massinon, B. (1984) Seismicity and dynamics of the Upper Rhine Graben. J. Geophysics 55, 1-12. 


\section{Active structures in central Upper Rhine Graben, SW Germany}

Buchmann, T. (2008): 3D multi-scale finite element analysis of the present-day crustal state of stress and the recent kinematic behaviour of the northern and central Upper Rhine Graben. Ph.D. thesis, Vrije Univ., Amsterdam.

Childs, C.; Nicol, A.; Walsh, J. and Watterson, J. (2003): The growth and propagation of synsedimentary faults. J. Struct. Geol. 25, 633-648.

Cloos, H. (1922): Über Ausbau und Anwendung der Granittektonischen Methode. Abh. Preuss. Geol. Landesans 89, 1-18.

Cornet, F.H.; Bérard, T. and Bourouis, S. (2007): How close to failure is a granite rock mass at a $5 \mathrm{~km}$ depth?. Intern. J. of Rock Mechanics and Mining Science 44, 47-66.

Delouis, B.; Haessler, H.; Cisternas, A. and Rivera, L. (1993): Stress tensor determination in France and neighbouring regions. Tectonophysics 221 (3-4), 413-437.

Derer, C. E. (2003) Tectonoseimentary evolution of the northern Upper Rhine Graben (Germany), with special regard to the early syn-rift stage. Ph. D thesis, University of Bonn, Bonn, 99pp.

Dezes, P.; Schmid, S.M. and Ziegler, P. A. (2004): Evolution of the European Cenozoic rift system. Interaction of the Alpine and Pyrenean orogens with their foreland lithosphere. Tectonophysics 389, 133.

Edel, J. B. and Weber, K. (1995): Cadomian terrains, wrench faulting and thrusting in the central Europe Variscides: Geophysical and geological evidence. Geol. Rundsch. 84, 412-432.

Faulds, J. E.; Coolbaugh, M.; Bouchot, V.; Moeck, I. and Oguz, K. (2010): Characterizing structural controls of the geothermal reservoirs in the Great Basin, USA, and western Turkey: developing successful exploration strategies in extended Terrains. Proc. World Geothermal Congress (2010), Bali, Indonesia, (25-29) April 2010, $11 \mathrm{p}$.

Faulds, J. E.; Coolbaugh, M.; Vice, G. S. and Edwards, M. L. (2006): Characterizing structural controls of geothermal fields in the north-western Great Basin-A progress report. GRC Transaction, San Diego, CA 30, 69-76.

Ferrill, D. A.; Winterle, J.; Wittmeyer, G.; Sims, D.; Colton, S.; Armstrong, A. and Morris, A. P. (1999): Stressed rock strains groundwater at Yucca Mountain, Nevada. GSA Today 9/5, 1-8.

Fracassi, U.; Niviére, B. and Winter, T. (2005): First appraisal to define prospective seismogenic sources from historical earthquake damages in southern Upper Rhine Graben. Quaternary Science Reviews 24, 401-423.

Frid, V.; Rabinovitch, A. and Bahat, D. (1999): Electromagnetic radiation associated with induced triaxial fracture in granite. Philosophical Magazine Letters 79, 79-86.

Frid, V.; Rabinovitch, A. and Bahat, D. (2003): Fracture induced electromagnetic radiation. Journal of Physics D: Applied Physics 36, 1620-1628.

Frietsch, M.; Groos, J.C. and Ritter, J. (2014): Detection and Delineation of a Fracture Zone with Observation of Seismic Shear Wave Anisotropy in the Upper Rhine Graben, SW Germany. Pure and Applied Geophysics, Published online 06 August 2014.

Fuhrmann, T.; Heck, B.; Knöpfler, A.; Masson, F.; Mayer, M.; Ulrich, P.; Westerhaus, M. and Zippelt, K. (2012): Recent surface displacements in the Upper Rhine Graben Preliminary results from geodetic networks. Tectonophysics 602, 300-315.

Gaßner, L.; Groos, J.C. and Ritter, J. (2014): Herdflächenanalyse induzierter Erdbeben in der Südpfalz: Reaktivierung präexistenter Bruchflächen und Spannungszustand. Mainzer Geowiss. Mitt. 42, Mainz, Germany, 195-214.

Gerard, A.; Genter, A.; Kohl, T.; Lutz, P.; Rose, P. and Rummel, F. (2006): The deep EGS (Enhanced Geothermal System) project at Soultz-sous-Forets (Alsace, France). Geothermics 35, 473-483.

Gershenzon, N. I.; Zilpimiani, D.; Mandzhgaladze, P. V.; Pokhotelov, O. A. and Chelidze, Z. T. (1986): Electromagnetic emission of the crack top during rupture of ionic crystals. Dokladi Akademii Nauk SSSR 288, 75-78.

Greiling, R. O and Obermeyer, H. (2010): Natural electromagnetic radiation (EMR) and its application in structural geology and neotectonics. J. Geol. Soc. of India 75(1), 278-288.

Groos, J. C.; Grund, M. and Ritter, J. (2012): Automated detection of microseismic events in the Upper Rhine Valley near the city of Landau/South Palatinate. Geophys. Res. Abstr.14, EGU2012-10482. 
Hagag, W.

Groos, J.; Zeiß, J.; Grund, M. and Ritter, J. (2013): Microseismicity at two geothermal power plants at Landau and Insheim in the Upper Rhine Graben, Germany. Geophys. Res. Abstr.15, EGU2013-2742.

Heidbach, O.; Tingay, M.; Barth, A.; Reinecker, J.; Kurfeß, D. and Müller, B. (2008): The World Stress Map database release 2008. doi:10.1594/GFZ.WSM.Rel2008 (available online at www.world-stressmap.org).

Hinzen, K. G. (2003): Stress field in the northern Rhine area, Central Europe, from earthquake fault plane solutions. Tectonophysics 377, 325-356.

Illies, J. H. (1962): Oberrheinisches Grundgebirge und Rheingraben. Geol. Rundsch. 52, 317- 332.

Illies, J. H. (1975): Intra-plate tectonics in stable Europe as related to plate tectonics in the Alpine system. Geol. Rundschau 64, 677-699.

Illies, J. H. (1977) Ancient and recent rifting in the Rhine Graben. Geologie en Mijnbouw 56, 329-350.

Illies, J.H. and Fuchs, K. (1974) Approaches to Taphrogenesis. Approaches to Taphrogenesis, 8. E. Schweizerbartsche Verlagsbuchhandlung (Nägele u. Obermiller), Stuttgart, 460pp.

Illies, J. H. and Greiner, G. (1978): Rhine Graben and the Alpine system. Bull. Geol. Soc. Am., 89, 770782.

Kastrup, U.; Zoback, M. L.; Deichmann, N.; Evans, K. F.; Giardini, D. and Michael, A. J. (2004): Stress field variations in the Swiss Alps and the northern Alpine foreland derived from inversion of fault plane solutions. J. Geophys. Res. 109, doi:10.1029/2003JB002550.

Knipe, R. J. (1997): Juxtaposition and seal diagrams to help analyze fault seals in hydrocarbon reservoirs. AAPG Bull. 81(2), 187-195.

Koktavy, P.; Pavelka, J. and Sikula, J. (2004): Characterization of acoustic and electromagnetic emission sources. Measurement Science and Technology 15, 973-977.

Larroque, J. M. and Laurent, P. (1988): Evolution of the stress field pattern in the southern of the Rhine Graben from the Eocene to the present. Tectonophysics 148, 41-58.

Lauterbach, M. (2005): Beurteilung der Eignung der NPEMFE-Methode (Natural Pulsed Electromagnetic Field of Earth) mit dem "Cereskop" in Rutschungen und in Locker- und Festgesteinen mit Spannungsänderungen im Mittel- und Hochgebirge. Ph. D. Thesis University of Mainz, 243 pp.

Leydecker, G. (2005): Erdbebenkatalog für die Bundesrepublik Deutschland mit Randgebieten für die Jahre 800-2004. Bundesanstalt für Geowissenschaften und Rohstoffe BGR, Hannover.

Lichtenberger, M. (2005): Regional stress field as determined from electromagnetic radiation in a tunnel. J. Struct Geol., 27, 2150-2158.

Lichtenberger, M. (2006a): Bestimmen von Spannungen in der Lithosphäre aus geogener elektromagnetischer Strahlung. Ph. D. Thesis, Univ. Heidelberg, 140 pp.

Lichtenberger, M. (2006b): Underground measurements of electromagnetic radiation related to stressinduced fractures in the Odenwald Mountains (Germany). Pure and Appl. Geophys. 163, 1661-1677.

Lopes Cardozo, G. G. O; Edel, J .B. and Granet, M. (2005): Detection of active crustal structures in the Upper Rhine Graben using local earthquake tomography, gravimetry and reflection seismics. Quaternary Sci. Review., 24, 337-344.

Mallik, J.; Mathew, G.; Angerer, T. and Greiling, R. O. (2008): Determination of directions of horizontal principal stress and identification of active faults in Kachchh (India) by electromagnetic radiation (EMR). J. Geodynamics 45, 234-245.

McCann, T. (2008): The Geology of Central Europe: Mesozioc and Cenozoic. The Geol. Soc. London 2, ISBN: 978-1-86239-264-9.

Michon, L.; Van Balen, R. T.; Merle, O. and Pagnier, H. (2003): The Cenozoic evolution of the Roer Valley Rift System integrated at an Europian scale. Tectonophys. 367, 101-126.

Misra, A. and Gosh, S. (1980): Electromagnetic radiation characteristics during fatigue crack propagation and failure. Applied Physics 23, 387-390.

Nocquet, J. M. and Calais, E. (2004): Geodetic measurements of crustal deformation in the Western Mediterranean and Europe. Pure Appl. Geophys.161, 661-681.

Obermeyer, H. (2001): Handbuch zur Anwendung der NPEMFE-Methode mittels des Cereskops. Ceres $\mathrm{GmbH}$, Staffort, $32 \mathrm{pp}$. 


\section{Active structures in central Upper Rhine Graben, SW Germany}

Obermeyer, H. (2005): Measurement of natural pulsed electromagnetic radiation (EMR) with the Cerescope. Ceres GmbH, Staffort.

Obermeyer, H.; Lauterbach, M. and Krauter, E. (2001) Monitoring landslides with natural electromagnetic pulse radiation. International Conference on Landslides, 297-304.

O'Keefe, S. O. and Thiel, D.V. (1995): A mechanism for the production of electromagnetic radiation during fracture of brittle materials. Physics of the Earth and Planetary Interiors 89, 127-135.

Peters, G. (2007): Active tectonics in the Upper Rhine Graben: Integration of paleoseismology, geomorphology and geomechanical modeling. Ph.D thesis, Vrije University, Amsterdam, published in Logos Verlage Berlin.

Peters, G. and Van Balen, R. T. (2007): Tectonic geomorphology of the northern Upper Rhine Graben, Germany. Global and Planetary Change 58, 310-334.

Plenefisch, T. and Bonjer, K. P. (1997): The stress field in the Rhine Graben area inferred from earthquake focal mechanisms and estimation of frictional parameters. Tectonophysics 275, 71-97.

Plenkers, K.; Ritter, J. and Schindler, M. (2013): Low signal- to-noise event detection based on waveform stacking and cross-correlation: application to a stimulation experiment. J. Seismol. 17, 27-49.

Prodehl, C.; Mueller, S. and Kaak, V. (1995): The European Cenozoic rift system. In: P.E. Olsen (Editor), Developments in Tectonics-Continental Rifts: Evolution, Structure and Tectonics. Elsevier Sci., New York, 133-212.

Rabinovitch, A.; Bahat, D. and Frid, V. (2002): Similarity and dissimilarity of electromagnetic radiation from carbonate rocks under compression, drilling and blasting. International Journal of Rock Mechanics and Mining Sciences 39,125-129.

Rabinovitch, A.; Frid, V. and Bahat, D. (2007): Surface oscillations-a possible source of fracture induced electromagnetic radiation. Tectonophysics 431, 15-21.

Rabinovitch, A.; Frid, V.; Bahat, D. and Goldbaum, J. (2000): Fracture area calculation from electromagnetic radiation and its use in chalk failure analysis. International Journal of Rock Mechanics and Mining Sciences 37, 1149-1154.

Reuther, C. and Moser, E. (2007): Orientation and nature of active crustal stresses determined by electromagnetic measurements in the Patagonian segment of the South America Plate. Inter. J. Earth Sci. 97, DOI 10.1007/s00531- 007-0273-0.

Reuther, C. and Moser, E. (2009): Orientation and nature of active crustal stresses determined by electromagnetic measurements in the Patagonian segment of the South America Plate. Intern. J. Earth Sci. 98, 585-599.

Reuther, C.; Obermeyer, H.; Reicherter, K.; Reiss, S.; Kaiser, A.; Buchmann, T.; Adam, J.; Lohrmann, J. and Grasso, M. (2002): Neotektonik und aktive Krustenspannung in Südost-Sizilien und ihre Beziehung zur regionalen Tektonik im Zentralen Mittelmeer. Mitteilungen Geologisches Paläontologisches Institut, Universität Hamburg 86, 1-24.

Rotstein, Y.; Edel, J. B.; Gabriel, G.; Boulanger, D.; Schaming, M. and Munschy, M. (2006): Insight into the structure of the Upper Rhine Graben and its basement from a new compilation of Bouguer Gravity. Tectonophysics 425, 55-70.

Rotstein, Y. and Schaming, M. (2011): The Upper Rhine Graben (URG) revisited: Miocene transtension and transpression account for the observed first-order structures. Tectonics 30 (3), TC3007, doi: $10.1029 / 2010 \mathrm{TC} 002767$.

Rozsa, S.; Heck, B.; Seitz, K.; Westerhaus, M. and Zippelt, K. (2005): Determination of displacements in the Upper Rhine Graben area from GPS and laveling data. Intern. J. Earth Sci. 94(4), 538-549.

Schindler, M.; Baumgärtner, J.; Gandy, T.; Hauffe, P.; Hettkamp, T.; Menzel, H.; Penzkofer, P.; Teza, D.; Tischner, T. and Wahl, G. (2010): Successful hydraulic stimulation techniques for electric power production in the Upper Rhine Graben, Central Europe. Proc. World Geothermal Congress, Bali, Indonesia, $7 \mathrm{pp}$.

Schlagenhauf, A.; Manighetti, I.; Malavieille, J. and Dominguez, S. (2008): Incremental growth of normal faults: Insights from a laser-equipped analog experiment. Earth and Planet. Sci. Lett. 273, 299-311.

Schumacher, M. E. (2002): Upper Rhine Graben: Role of preexisting structures during rift evolution. Tectonics 21(1): 10.1029/2001TC900022. 
Hagag, W.

Sissingh, W. (1998): Comparative Tertiary stratigraphy of the Rhine Graben, Bresse Graben and Molasse Basin: Correlation of Alpine Foreland events. Tectonophys. 300, 249-284.

Sittler, C. and Sonne, V. (1971) Vorkommen und Verbreitung eozäner Ablagerungen im nördlichen Mainzer Becken. N. Jb. Geol. Paläont. Mh., 372-384.

Slifkin, L. (1993): Seismic electric signals from displacement of charged dislocations. Tectonophysics 224, 149-152.

Takeuchi, A. and Nagahma, H. (2006): Electric dipoles perpendicular to a stick-slip plane. Physics of the Earth and Planetary Interiors 155, 208-218.

Tesauro, M.; Hollenstein, C.; Egli, R.; Geiger, A. and Kahle, H. G. (2005): Continuous GPS and broadscale deformation across the Rhine Graben and the Alps. Intern. J. Earth Sci. 94(4), 525-537.

Tesauro, M.; Hollenstein, C.; Egli, R.; Geiger, A. and Kahle, H. G. (2006) Analysis of central western Europe deformation using GPS and seismic data. J. Geody. 42, 194-209.

Ustaszewski, K. and Schmid, S. M. (2007): Latest Pliocene to recent thick-skinned tectonics at the Upper Rhine Graben- Jura Mountains junction. Swiss j. geosci. 100, 293-312

Ustaszewski, K.; Schumacher, M. E.; Schmid, S.M. and Nieuwland, D. (2005a): Fault reactivation in brittle-viscous wrench systems - dynamically scaled analogue models and application to the RhineBresse Transfer Zone. Quater., Sci., Rev. 24, 363-380.

Ustaszewski, K.; Schumacher, M. E. and Schmid, S. M. (2005b): Simultaneous normal faulting and extensional flexuring during rifting: an example from the southernmost Upper Rhine Graben. Intern. J. Earth Sci. 94, 680-696.

Vigny, C.; Chery, J.; Duquesnoy, T.; Jouanne, F.; Ammann, J.; Anzidi, M.; Avouac, J. P.; Barlier, F.; Bayer, R.; Briole, P.; Calais, E.; Cotton, F.; Duquenne, F.; Feigl, K. L.; Ferhat, G.; Flouzat, M.; Gamond, J. F.; Geiger, A.; Harmel, A.; Kasser, M.; Laplanche, M.; Le Pape, M.; Martinod, J.; Menard, G.; Mayer, B.; Ruegg, J. C.; Scheubel, J. M.; Scotti, O. and Vidal, G. (2002): GPS network monitors the western Alps' deformation over a five-year period: 1993-1998. J. Geodesy 76, 63-76.

Villemin, T.; Alvarez, F. and Angelier, J. (1986): The Rhine Graben: Extension, Subsidence and Shoulder Uplift. Tectonophysics 128, 47-59.

Wittmann, O. (1955): Bohnerz und präeozäne Landoberfläche im Markgräflerland. Jh. Geol. Landesamt Baden-Württemberg 1, 267-299.

Yielding, G.; Freeman, B. and Needham, D. T. (1997): Quantitative fault seal prediction. AAPG Bull. 81(6), 897-917.

Ziegler, P. A. (1990): Collision related intra-plate compression deformations in Western and Central Europe. J. Geody. 11, 357-388.

Ziegler, P. A. (1992): European Cenozoic rift system. Tectonophysics 208, 91-111.

Ziegler, P.A. (1994): Cenozoic rift system of western and central Europe: An overview. Geologie en Mijnbouw 73, 99-127. 


\section{Active structures in central Upper Rhine Graben, SW Germany}

Landau التراكيب النشطة في منطقة وسط حوض الراين العليا ، جنوب غرب ألمانيا: بيانات جليدة من منطقة لانداو

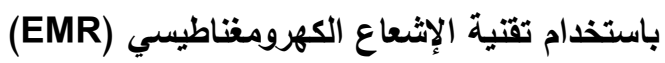

وائل حجاج

قسم الجيولوجيا- كلية العلوم - جامعة بنها

الخلاصة

تم الكثف عن نظامين مترافقتين من الصدوع النشطة الموجهة شمال شمال شرق- جنوب جنوب غرب و شمال شمال غرب-جنوب جنوب شرق في منطقة لانداو في جنوب غرب ألمانيا. وتتبع هذه الصدوع الاتجاهات القديمة للتراكيب المرتبطة

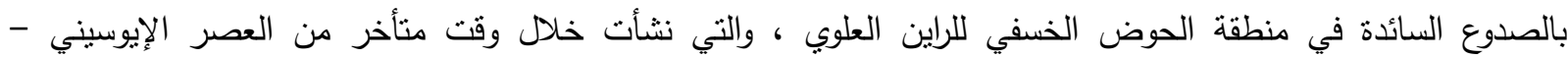
الميوسيني.

تم إجراء القياسات الخطية والأفقية باستخدام جهاز سيريسكوب وتفسيرها، مع تطبيق تقنية الإشعاع الكهرومغناطيسي (EMR) (الت القطاعات الكهرومغناطيسية الخطية مفيدة في نخريط الصدوع النشطة، في حين تم تحديد الضغط الأفقي

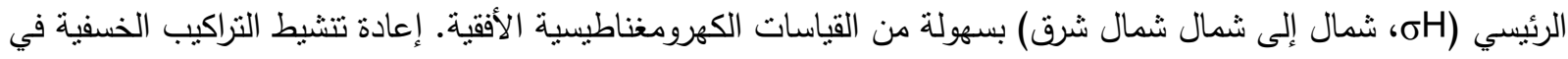
حوض الراين العلوي في منطقة لانداو قد نتج عنه نظام حديث من الكسور الضحلة النشطة متخذة الاتجاهات القديمة، وقد تم التعرف علي ذلك في هذه الدراسة باستخدام جهازالسيريسكوب و نطبيق تقنية EMR. وتثير النتائج الحالية إلى أن نظام/محطة الطاقة الحرارية الأرضية في جنوب لانداو له تأثير كبير على إعادة تتشيط

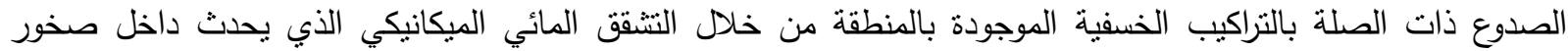
الخزان المتواجد أسفل منطقة الدراسة. 